\title{
PEMBERDAYAAN EKS TKI TENTANG PERBAIKAN DAN PEMELIHARAAN INSTALANSI LISTRIK, AC, RUMAH TINGGAL 1 FACE (PENGABDIAN MASYARAKAT BAGI EKS TKI CAB. SUBANG
}

\author{
Drs. Irzan Zakir, M.Pd \\ Fakultas Teknik Universitas Negeri Jakarta
}

\begin{abstract}
ABSTRAK
Perkembangan teknologi di bidang teknik instalasi listrik sangat berkembang pesat dan beragam. Untuk memasang instalasi listrik tersebut perlu perencanaan dan pemasangan instalasi listrik sesuai yang sistematis sesuai dengan prosesdur dan standar yang telah ditetapkan melalui Persyaratan Umum Instalasi Listrik (PUIL) tahun 2010, secara berkala ataupun pemeliharaan dan perbaikan yang bersifat situasional sesuai kebutuhan. Kebutuhan tersebut memerlukan teknisi yang handal, yang memiliki pengetahuan, keterampilan, kemampuan dan menguasai serta dapat mengatasi permasalahan yang ada dikelistrikan.

Salah satu Pengabdian Kepada Masyarakat yang dilakukan Dosen sebagai sumbangsih terhadap kepedulian lingkungan sekitarnya adalah dengan memberikan pengetahuan ketrampilan Teknik Instalasi Listrik AC 1 fase di rumah tinggal yang sangat bermanfaat bagi masyarakat khususnya bagi eks Tenaga Kerja Indonesia yang pernah bekerja di luar negeri di wilayah Kecamatan Pagaden, Kabupaten Subang, Jawa Barat.

Kegiatan ini diharapkan dapat memberikan maafaat agar Peserta menguasi tentang Teknik Instalasi Listrik penerangan dan tenaga AC 1 fase, Peserta juga mampu menguasai hubungan dasar instalasi listrik dengan baik dan benar, serta memberi ilmu yang konkrit dan bermanfaat setelah peserta Eks TKI pria dan wanita memiliki pengetahuan dan keterampilan dalam bidang teknik instalasi listrik AC 1 fase dengan baik dan benar.

Universitas negeri Jakarta bekerja sama dengan Pemerintah Daerah Kabupaten Subang, Jawa Barat untuk kegiatan - kegiatan Pengabdian Pada Masyatrakat yang tepat guna dan tepat sasaran, khususnya dan pada umumnya Pemerintah Provinsi Jawa Barat. Sehingga manfaat pengabdian masyarakat benar - benar turun ke bawah atau kelapangan.
\end{abstract}

\section{PENDAHULUAN}

A. LATAR BELAKANG MASALAH

Tri Darma Perguruan Tinggi, yaitu Pendidikan, Penelitian dan Pengabdian Kepada Masyarakat merupakan hal yang mutlak dilakukan oleh para dosen atau staf pengajar sebagai Strategi instruksional dalam meningkatkan hasil belajar teori dan praktek yang dilaksanakan di kampus, dan salah satunya adalah Pengabdian Kepada Masyarakat yang dilakukan Dosen sebagai sumbangsih terhadap kepedulian lingkungan sekitarnya sehingga masyarakat dapat memperoleh suatu bentuk pelatihan ketrampilan yang berguna kelak di kemudian hari, khususnya di Universitas Negeri Jakarta di Tahun 2016.

Perkembangan teknologi di bidang teknik instalasi listrik sangat berkembang pesat dan beragam. Untuk memasang instalasi listrik tersebut perlu perencanaan dan pemasangan instalasi listrik sesuai yang sistimatis sesuai dengan prosedur dan standar yang telah ditetapkan melalui Persyaratan Umum Instalasi Listrik (PUIL) tahun 2010, secara berkala ataupun pemeliharaan dan perbaikan yang bersifat situasional sesuai kebutuhan. Kebutuhan tersebut memerlukan teknisi yang handal, yang memiliki pengetahuan, keterampilan, kemampuan dan menguasai serta dapat mengatasi permasalahan yang ada dikelistrikan.

Berdasarkan rasional maka dapat diidentifikasikan masalah sebagai beikut: Bagaimanakah memberikan pengetahuan ketrampilan Teknik Instalasi Listrik AC 1 fase di rumah tinggal yang sangat bermanfaat bagi masyarakat khususnya 
bagi eks Tenaga Kerja Indonesia yang pernah bekerja di luar negeri seperti Saudi Arabia, Suriah, Kuwait, Irak, Hongkong, Taiwan, Malaysia dan singapore?

Untuk pemecahan masalah dalam pengabdian pada masyarakat ini, maka dilakukan suatu pendataan warga masyarakat di sekitar Kecamatan Pagaden umumnya, khususnya di Desa kamarung, yang inputnya peserta Eks TKI yang bersedia diberikan pengetahuan teori tentang kelistrikan dan punya kemauan dan keinginan yang kuat untuk memperoleh pengetahuan ilmu secara teori dan praktik teknik instalasi listrik rumah tinggal 1 fase, peserta khususnya Eks TKI laki laki dan perempuan sebanyak 13 orang yang mewakili mengikuti kegiatan pelatihan ketrampilan teknik instalasi listrik rumah tinggal 1 fase di salah satu Aula / ruang pertemuan di Balai desa Kamarung, Kecamatan Pagaden, Subang, Jawa Barat.

\section{B. PERUMUSAN MASAlAH :}

Berdasarkan rasional maka dapat diidentifikasikan masalah sebagai berikut: Bagaimanakah memberikan pengetahuan ketrampilan Teknik Instalasi Listrik rumah tinggal 1 Fase yang sangat bermanfaat bagi masyarakat khususnya Eks TKI di Kabupaten Subang baik pria dan wanita dengan baik dan benar bagi masyarakat khususnya sekitar kecamatan Pagaden ,Kabupaten Subang, Provinsi Jawa Barat?

\section{TUJUAN KEGIATAN :}

Adapun pelatihan ketrampilan ini bertujuan untuk berbakti kepada masyarakat di luar lingkungan kampus, sehingga mendapatkan bekal yang positif bagi para Eks TKI pria dan wanita tentang pengetahuan dan ketrampilan teknik instalasi listrik AC 1 fase dengan baik dan benar serta sebagai modal berwirausaha kelak di kemudian hari.

\section{MANFAAT KEGIATAN :}

Setelah kegiatan pelatihan ini maka dapat diuraikan manfaat yang nyata, yaitu sebagai berikut :

1. Peserta menguasi tentang Teknik Instalasi Listrik penerangan dan tenaga $\mathrm{AC} 1$ fase.

2. Mampu menguasai hubungan dasar instalasi listrik dengan baik dan benar.
3. Memberi ilmu yang konkrit dan bermanfaat setelah peserta Eks TKI pria dan wanita memiliki pengetahuan dan keterampilan dalam bidang teknik instalasi listrik AC 1 fase dengan baik dan benar.

\section{TINJAUAN PUSTAKA}

A. KAJIAN TEORI:

Pelatihan ketrampilan Teknik Instalasi Listrik ini memiliki urutan kajian teori pendukung dalam ranah kognitf, sehingga para peserta juga mengerti pengetahuan-pengetahuan tentang kelistrikan yang baik dan handal, secara garis besar maka dapat diuraikan sebagai berikut:

1. Peraturan Pemasangan Instalasi Listrik.

2. Perencanaan dan Pemasangan Instalasi Listrik.

3. Langkah-langkah tentang Keselamatan Kerja.

4. Macam-macam hubungan dasar kelistrikan.

5. Contoh aplikasi teknik instalasi listrik yang ada di lapangan.

\section{B. PERATURAN PEMASANGAN INSTALASI LISTRIK}

\section{Tujuan Peraturan}

Persyaratan umum instalasi listrik (PUIL) tahun 2010, bertujuan untuk terselenggaranya dengan baik suatu pemasangan instalasi listrik, terutama yang menyangkut keselamatan manusia terhadap bahaya sentuhan serta kejutan arus, keamanan instalasi listrik serta perlengkapannya, dan keamanan gedung serta isinya terhadap kebakaran akibat listrik.

Dengan adanya peraturan yang harus diikuti sebagai rambu-rambu pekerjaan maka pekerjaan akan lebih tertib dan teratur, sehingga memudahkan untuk mencapai tujuan serta memudahkan bagi pihak berwenang. Mengingat pemasangan instalasi rumah cukup rumit karena menyangkut kenyamanan dan keselamatan bagi pemakainya serta kelangsungn keandalan , keawetan instalasi, dan komponennya maka perlu suatu aturan khusus yang harus dipatuhi dalam pemasangan instalasi.

Instalasi listrik merupakan susunan perlengkapan-perlengkapan listrik yang saling berhubungan serta memiliki ciri terkoordinasi untuk memenuhi satu atau sejumlah tujuan tertentu. Instalasi listrik terdiri atas sistem penerangan, sistem pensaklaran, sistem pengkabelan, sistem pembumian dan sistem lain yang yang dibutuhkan. Instalasi listrik dapat berupa sebuah instalasi 
yang sederhana yang hanya terdiri atas satu titik atau satu instalasi listrik yang rumit dan kompleks. Instalasi listrik rumah tangga secara umum adalah untuk kebutuhan penerangan dan kebutuhan sumber tenaga listrik untuk peralatan-peralatan listrik yang digunakan, seperti pemanas makanan, setrika listrik, dll.

\section{Keselamatan Kerja}

Dalam pemasangan instalasi listrik, biasanya rawan terhadap terjadinya kecelakaan. Kecelakaan bisa timbul akibat adanya sentuh langsung dengan penghantar beraliran arus atau kesalahan dalam prosedur pemasangan instalasi. Oleh karena itu perlu diperhatikan hal-hal yang berkaitan dengan bahaya listrik serta tindakan keselamatan kerja. Bebrapa penyebab terjadinya kecelakaan listrik diantaranya :

a. Kabel atau hantaran pada instalasi listrik terbuka dan apabila tersentuh akan menimbulkan bahaya kejut

b. Jaringan dengan hantaran telanjang

c. Peralatan listrik yang rusak

d. Kebocoran lsitrik pada peralatan listrik dengan rangka dari logam, apabila terjadi kebocoran arus dapat menimbulkan tegangan pada rangka atau body

e. Peralatan atau hubungan listrik yang dibiarkan terbuka

f. Penggantian kawat sekring yang tidak sesuai dengan kapasitasnya sehingga dapat menimbulkan bahaya kebakaran

g. Penyambungan peralatan listrik pada kotak kontak (stop kontak) dengan kontak tusuk lebih dari satu (bertumpuk).

Contoh langkah-langkah keselamatan kerja berhubungan dengan peralatan listrik, tempat kerja, dan cara-cara melakukan pekerjaan pemasangan instalasi lisrik dapat diikuti pentunjuk berikut :

1. Menurut PUIL ayat 920 B6, beberapa ketentuan peralatan listrik diantaranya :

a) Peralatan yang rusak harus segera diganti dan diperbaiki. Untuk peralatan rumah tangga seperti sakelar, fiting, kotak-kontak, setrika listrik, pompa listrik yang dapat mengakibatkan kecelakaan listrik.

b) Tidak diperbolehkan :
- Mengganti pengaman arus lebih dengan kapasitas yang lebih besar

- Mengganti kawat pengaman lebur dengan kawat yang kapasitasnya lebih besar

- Memasang kawat tambahan pada pengaman lebur untuk menambah daya

c) Bagian yang berteganagan harus ditutup dan tidak boleh disentuh seperti terminalterminal sambungan kabel, dan lain-lain

d) Peralatan listrik yang rangkaiannya terbuat dari logam harus ditanahkan

2. Menurut PUIL ayat $920 \mathrm{~A} 1$, tentang keselamatan kerja berkaitan dengan tempat kerja, diantaranya :

a) Ruangan yang didalamnya terdapat peralatan 1sitrik terbuka, harus diberi tanda peringatan "AWAS BERBAHAYA"

b) Berhati-hatilah bekerja dibawah jaringan listrik

c) Perlu digunakan perelatan pelindung bila bekerja di daerah yang rawan bahaya listrik

3. Pelaksanaan pekerjaaan instalasi listrik yang mendukung pada keselamatan kerja, antara lain:

a) Pekerja instalasi listrik harus memiliki pengetahuan yang telah ditetapkan oleh PLN (AKLI)

b) Pekerja harus dilengkapi dengan peralatan pelindung seperti : Baju pengaman (lengan panjang, tidak mengandung logam, kuat dan tahan terahadap gesekan), Sepatu, Helm, Sarung tangan.

c) Peralatan (komponen) listrik dan cara pemasangan instalasinya harsus sesuai dengan PUIL.

d) Bekerja dengan menggunakan peralatan yang baik

e) Tidak memasang tusuk kontak secara bertumpuk

f) Tidak boleh melepas tusuk kontak dengan cara menarik kabelnya, tetapi dengan cara memegang dan menarik tusuk kontak tersebut. 


\section{Peraturan}

Sistem penyaluran dan cara pemasangan instalasi listrik di Indonesian harus mengikuti aturan yang ditetapkan oleh PUIL (Peraturan umum Instalasi Listrik) yang diterbitkan tahun 1977, kemudian direvisi tahun 1987 dan terakhir tahun 2000. Tujuan dari Peraturan umum Instalasi Listrik di Indonesia adalah:

1. Melindungi manusia terhadap bahaya sentuhan dan kejutan arus listrik.

2. Keamanan instalasi dan peralatan listrik.

3. Menjaga gedung serta isinya dari bahaya kebakaran akibat gangguan listrik.

4. Menjaga ketenagaan listrik yang aman dan efisien.

Agar energi listrik dapat dimanfaatkan secara aman dan efisien, maka ada syarat-syarat yang harus dipatuhi oleh pengguna energi listrik. Peraturan instalasi listrik terdapat dalam buku Peraturan Umum Instalasi Listrik atau yang seing disingkat dengan PUIL. Di mulai dari tahun 2000, kemudian direviri tahun 1987, dan terakhir tahun 2000. Sistem instalasi listrik yang dimulai dari sumber listrik (tegangan, frekwensi), peralatan listrik, cara pemasangan, pemeliharaan dan keamanan, sudah diataur dalam PUIL. Jadi setiap perencana instalasi listrik, instalatir (pelaksana), Operator, pemeriksa dan pemakai jasa listrik wajib mengetahui dan memahami Peraturan Umum Instalasi listrik (PUIL).

PUIL tidak berlaku bagi beberapa sistem intalasi listrik tertentu seperti :

1. Bagian instalasi tegangan rendah untuk menyalurkan berita atau isyarat.

2. Instalasi untuk keperluan telekomunikasi dan instalasi kereta rel listrik.

3. Instalasi dalam kapal laut, kapal terbang, kereta rel listrik, dan kendaraan yang digerakan secara mekanis.

4. Instalasi listrik pertambangan di bawah tanah.

5. Instalasi tegangan rendah tidak melebihi 25 $\mathrm{V}$ dan daya kurang dari $100 \mathrm{~W}$.

6. Instalasi khusus yang diawasi oleh instansi yang berwenang (misalnya: instalasi untuk telekomunikasi, pengawasan, pembangkitan, transmisi, distribusi tenaga listrik untuk daerah wewenang instansi kelistrikan tersebut).
Pada ayat 103 A1 dari PUIL merupakan peraturan lain yang berkaitan dengan instalasi listrik, yakni:

a. Undang-Undang No. 1 tahun 1970, tentang Keselamatan Kerja.

b. Peraturan Bangunan Nasional.

c. Peraturan Pemerintah No. 18 tahun 1972, tentang Perusahaan Listrik Negara.

d. Peraturan lainnya mengenai kelistrikan yang tidak bertentangan dengan PUIL.

Suatu peralatan listrik boleh dipergunakan untuk instalasi apabila:

a) Memenuhi ketentuan-ketentuan PUIL 2000.

b) Telah mendapat pengesahan atau izin dari instansi yang berwenang (ayat 202 A2)

Berdasarkan ketentuan PUIL 2000 ayat 202 B1: semua instalasi yang selesai dipasang sebelum dipergunakan harus diperiksa dan diuji lebih dahulu. Menurut ayat 110 T16, tegangan dibagi menjadi :

a. Tegangan rendah ( sampai $1000 \mathrm{~V}$ )

b. Tegangan Menengah $(1000 \mathrm{~V}-20 \mathrm{kV})$

c. Tegangan Tinggi (di atas $20 \mathrm{kV}$ )

\section{Pengujian Peralatan Listrik}

Di negara kita semua peralatan listrik sebelum digunakan oleh konsumen harus melalaui uji kelayakan. Menurut ayat 202 A2 semua peralatan listrik yang akan dipergunakan instalasi harus memenuhi ketentuan PUIL. Di Indonesia peralatan listrik diuji oleh suatu lembaga dari Perusahaan Umum Listrik Negara, yaitu Lembaga Masalah Kelistrikan disingkat LMK.

Gambar 1: Tanda Persetujuan Pengujiam dari LMK

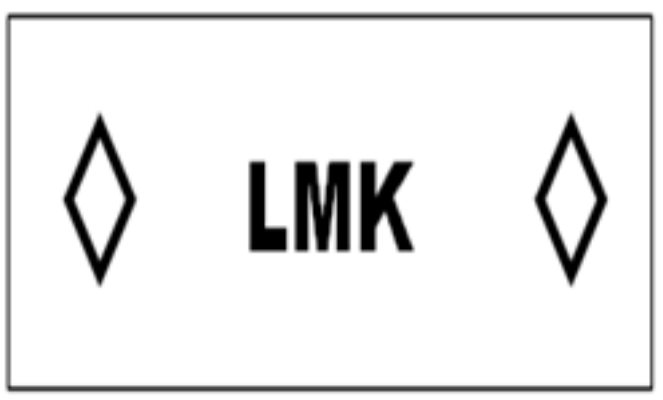

Peralatan listrik yang mutunya diawasi oleh LMK dan disetujui, diizinkan untuk memakai tanda LMK. Bahan yang berselubung bahan termo- 
plastik, misalnya berselubung PVC, tanda ini dibuat timbul dan diletakan pada selubung luar kabel.

Lambang persetujuan ini dipasang pada kabel yang berselubung PVC, misalnya kabel NYM. Sedangkan unruk kabel yang kcelil seperti NYA, lambang persetujuan dari LMK berupa kartu yang ditunjukan pada gambar 2 .

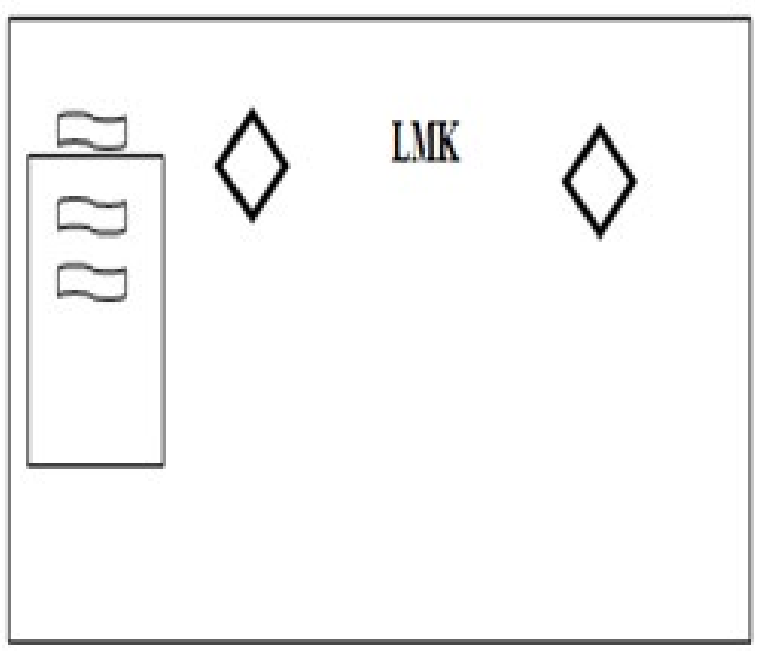

Di negara kita peralatan listrik yang telah diawasi mutu produksinya oleh LMK baru kabelkabel buatan dalam negeri.

\section{Komponen Instalasi Listrik}

Komponen instalasi listrik merupakan perlengkapan yang paling pokok dalam suatu rangkaian instalasi listrik. Dalam pemasangan instalasi listrik banyak macamnya, untuk memudahkan bagi siswa/instalatir komponen tersebut dikelompokan:
a. Bahan Penghantar
b. Kotak Kontak
c. Fiting
d. Saklar
e. Pengaman
f. Peralatan Pelindung

Komponen instalasi listrik yang akan dipasang pada instalasi listrik, harus memenuhi persyaratan sebagai berikut:

a) Keandalan, menjamin kelangsungan kerja instalasi listrik pada kondisi normal.

b) Keamanan, komponen instalasi yang dipasang dapat menjamin keamanan system instalasi listrik. c) Kontinuitas, komponren dapat bekerja secara terus menerus pada kondisi normal.

\section{Bahan Penghantar}

\section{a. Jenis Bahan Penghantar}

Penghantar yang digunakan pada instalasi listrik pada umumnya digunakan bahan tembaga dan alumunium. Alumunium untuk penghantar kabel berisolasi harus juga alumunium murni. umumnya digunakan alumunium dengan kemurnian sekurang-kurangnya 99,9\%. Tahanan jenis alumunium lunak untuk hantaran listrik telah dibakukan, yaitu tidak boleh melebihi 0,028264 ohm $\mathrm{mm} 2 / \mathrm{m}$ pada suhu $200 \mathrm{C}$; atau sama dengan daya hantar sekurang-kurangnya 61\% IACS (international Annealid Copper Standard). Daya hantar alumunium juga dipengaruhi oleh keadaan kekerasannya, tetapi tak sebesar daya hantar tembaga. Alumunium lunak dengan daya hantar 61\% IACS, memiliki kekuattan tarik 60-70N/ $\mathrm{mm} 2$. Alumunium keras dengan kekuatan tarik $150-159 \mathrm{~N} / \mathrm{mm} 2$ hanya kira-kira $1 \%$ lebih rendah daripada daya hantar alumunium lunak. Koefisien suhu pada suhu awal $200 \mathrm{C}$ adalah $0,04 \%$ per derajat celcius dan berat jenisnya pada suhu tersebut 2,7 dan 8,9. Daya alumunium sama dengan $61 \%$ IAC, maka tahanan penghantar yang sama diperlukan luas penghantar :

$100 / 60 \mathrm{x}$ luas penghantar tembaga $=1,64 \mathrm{x}$ luas penghantar tembaga atau jika memperhitungkan diameter penghantar $=\mathrm{x}$ diameter tembaga. Berat alumunium juka dibanding dengan berat tembaga : $1,64 \times(2,7 / 8,9) \times 100 \%=50 \%$ berat tembaga. Jadi penghantar alumunium dibanding dengan tembaga akan 50\% lebih ringan, tetapi diameter akan 28\% lebih besar. Hal berarti penggunaan kawat alumunium akan lebih hemat dan penggunaan isolasi lebih sedikit, karena diameternya lebih besar $28 \%$.

\section{b. Kabel Instalasi Berselubung}

Penggunaan kabel instalasi berselubung jika dibandingkan dengan dalam pipa diantaranya :

1. Lebih mudah dibengkokan

2. Lebih tahan terhadap pengaruh asam dan uap atau gas tajam

3. Sambungan dengan alat pemakai dapat ditiup lebih rapat 
Beberapa pengertian huruf yang digunakan pada kode kabel adalah :

$\mathrm{N}$ : Kabel standar dengan penghantar tembaga

NA : Kabel standar dengan penghantar aluminium

Y : Isolasi atau selubung PVC

F : Perisai kawat baja pipih

$\mathrm{R}$ : Perisai kawat baja bulat

$\mathrm{Gb}:$ Spiral pita baja

re : Penghantar padat bulat

rm : Penghantar bulat kawat banyak

se : Penghantar padat bentuk sektor

sm : Penghantar kawat banyak bentuk sector

\section{Contoh :}

NAYFGbY 4 x 120 SM 0,6/1 kV

Artinya : kabel jenis standar dengan penghantar aluminium kawat banyak bentuk sektor, berisolasi dan berselubung PVC, dengan perisai kawat baja pipih dan spiral pita baja. Jumlah urat empat, luas penampang nominal masing-masing $120 \mathrm{~mm} 2$, dan tegangan kerja nominal $0,6 / 1 \mathrm{kV}$.

Salah satu jenis kabel instalasi berselubung adalah kabel jenis NYM, dimana kabel ini memiliki penghantar tembaga polos bersiolasi PVC dengan luas penampang $1,5 \mathrm{~mm} 2-10 \mathrm{~mm} 2$ dan penghantarnya kawat tunggal. Untuk penampang 16 $\mathrm{mm} 2 \mathrm{ke}$ atas penghantarnya terdiri atas sejumlah kawat yang dipilin menjadi satu.

\begin{tabular}{|l|l|l|}
\hline $\begin{array}{l}\text { Luas penampang } \\
\text { nominal kabel }\end{array}$ & $\begin{array}{l}\text { Kemampuan hantar } \\
\text { arus maksimum }\end{array}$ & $\begin{array}{l}\text { Kemampuan hantar arus } \\
\text { Bominal maksimum pengaman }\end{array}$ \\
\hline $\mathrm{mm}^{2}$ & A & A \\
\hline 1,5 & 19 & 20 \\
2,5 & 25 & 25 \\
4 & 34 & 35 \\
6 & 44 & 50 \\
10 & 61 & 63 \\
16 & 82 & 80 \\
25 & 108 & 100 \\
35 & 134 & 125 \\
50 & 167 & 160 \\
70 & 207 & 224 \\
95 & 249 & 250 \\
120 & 291 & 300 \\
150 & 334 & 355 \\
185 & 380 & 355 \\
240 & 450 & 425 \\
300 & 520 & 500 \\
\hline
\end{tabular}

Kemampuan menghantar arusnya dari kabel NYM ini dapat dijelaskan pada tabel 2.2. Tbel 2.2 ini berlaku untuk semua kabel instalasi yang berisolasi dan berselubung PVC termasuk kabel fleksibel dengan penghantar tembaga suhu maksimum 70OC pada suhu keliling 30OC.

Tabel 2. Kemampuan hantar arus kabel instalasi berisolasi dan berselubung PVC

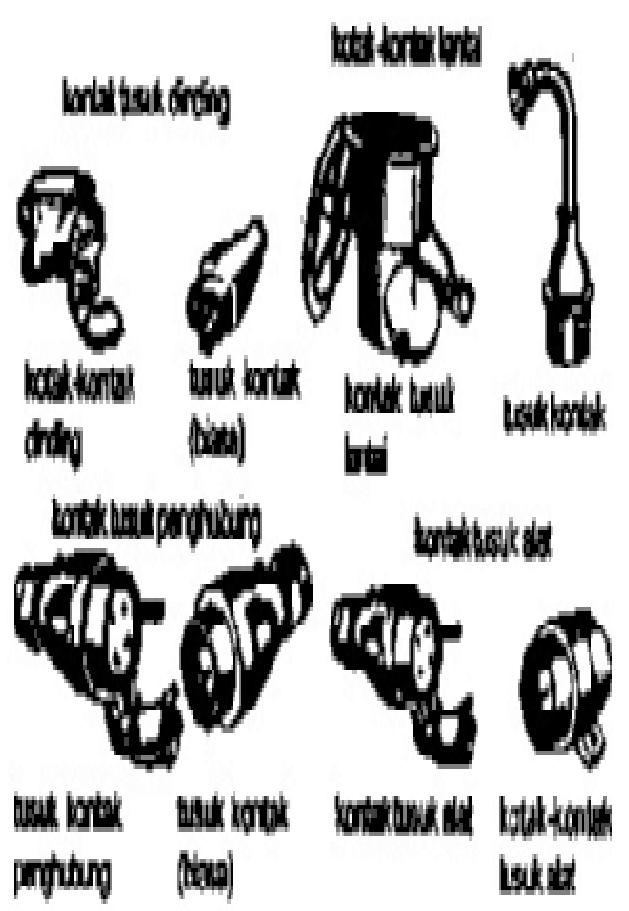

Tabel 3. Warna selubung luar kabel PVC

\begin{tabular}{|l|l|c|}
\hline \multicolumn{1}{|c|}{ Jenis Kabel } & $\begin{array}{c}\text { Tegangan } \\
\text { Nominal }\end{array}$ & $\begin{array}{c}\text { Warna } \\
\text { Selubung } \\
\text { Luar }\end{array}$ \\
\hline $\begin{array}{l}\text { Kabel berselubung } \\
\text { PVC untuk instalasi } \\
\text { tetap (misal NYM) }\end{array}$ & $500 \mathrm{~V}$ & Putih \\
\hline $\begin{array}{l}\text { Hantaran udara } \\
\text { berselubung } \\
\text { PVC } \\
\text { (misal NYMI) }\end{array}$ & $500 \mathrm{~V}$ & Hitam \\
\hline $\begin{array}{l}\text { Kabel } \\
\text { berselubung PVC }\end{array}$ & $0.6 / 1 \mathrm{kV}$ & Hitam \\
\hline $\begin{array}{l}\text { Kabel } \\
\text { berselubung PVC }\end{array}$ & $1 \mathrm{kV}$ & Merah \\
\hline
\end{tabular}




\section{Kontak Listrik}

\section{a. Kotak-Kontak (Stop Kontak)}

Kotak kontak merupakan tempat untuk mendapatkan sumber tegangan listrik yang diperlukan untuk pesawat atau alat listrik. Tegangan Sunber listrik ini diperoleh dari hantaran fasa dan netaral yang berasal dari PLN. Simbol dan jenis kotak kontak dapat dilihat pada gambar.

Gambar 3 Lambang dan bentuk kontak listrik

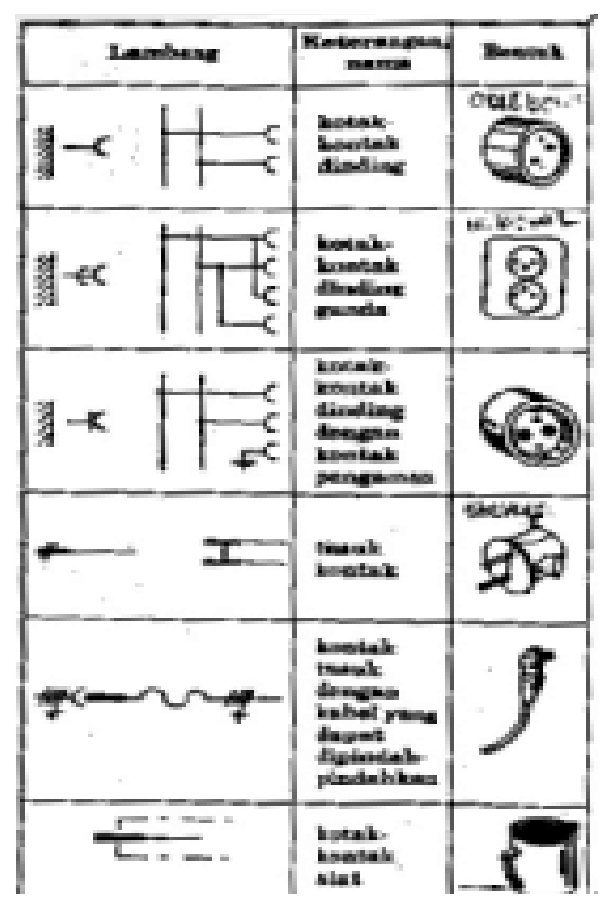

\section{b. Kontak Tusuk}

Kontak tusuk digunakan untuk menghubungkan pesawat atau alat listrik yang dipasang tetap ataupun dapat dipindah-pindahkan. Jenis kontak tusuk dapat dilihat pada gambar.

Gambar 4 Jenis-jenis kontak tusuk

Penggunaan dan pemasangan kontak ada beberapa ketentuan antara lain :

a. Kotak-kontak dinding fasa satu harus dipasang hingga kontak netralnya ada disebelah kanan (ayat 206 B4).

b. Kotak-kontak dinding yang dipasang kurang dari 1,25 meter di atas lantai harus dilengkapi dengan tutup (ayat $840 \mathrm{C} 5$ )

c. Kotan-kontak yang dipasang dilantai harus tertutup (ayat 511 B4) d. Kotak-kontak dinding dengan pengaman harus dipasang hantaran pengaman (ayat 321 B1 sub b4)

e. Ruangan yang dilengkapi dengan kotak kontak dengan kotak pengaman, tidak boleh dipasang kotak-kontak tanpa pengaman, kecuali kotak-kontak tegangan rendah dan untuk pemisahan pengaman (ayat 321 B1 sub b4)

f. Pada satu tusuk kontak, hanya boleh dihubungkan satu kabel yang dapat dipindah-pindah (ayat 511 A9 sub c)

g. Kemampuan kotak-kontak harus sekurangkurangnya sesuai dengan daya yang dihubungkan padanya, tetapi tidak boleh kurang dari 5 A (ayat $840 \mathrm{C} 6$ ).

\section{Kontak Hubung Bagi}

Kotak PHB harus dibuat dari bahan yang tidak dapat terbakar, tahan lembab dan kukuh (ayat 610 A1). Pada setiap hantaran fasa keluar suatu perlengkapan hubung bagi harus dipasang pengaman arus (ayat 602 D1). Pada hantaran netral tidak boleh dipasang pengaman arus, kecuali bila potensial hantaran netralnya tidak selalu mendekati potensial tanah. Setiap peralatan listrik, kecuali kotak-kontak dengan kemampuan hantar arus nominal $16 \mathrm{~A}$ atau lebih, harus merupakan rangkaian akhir tersendiri kecuali jika peralatan tersebut bagian yang tidak terpisahkan dari suatu unit instalasi (ayat 602 N1). Gambar 5a memperlihatkan diagram rangkaian akhir sederhana untuk satu fasa, dan gambar $5 \mathrm{~b}$ menunjukkan bentuknya.

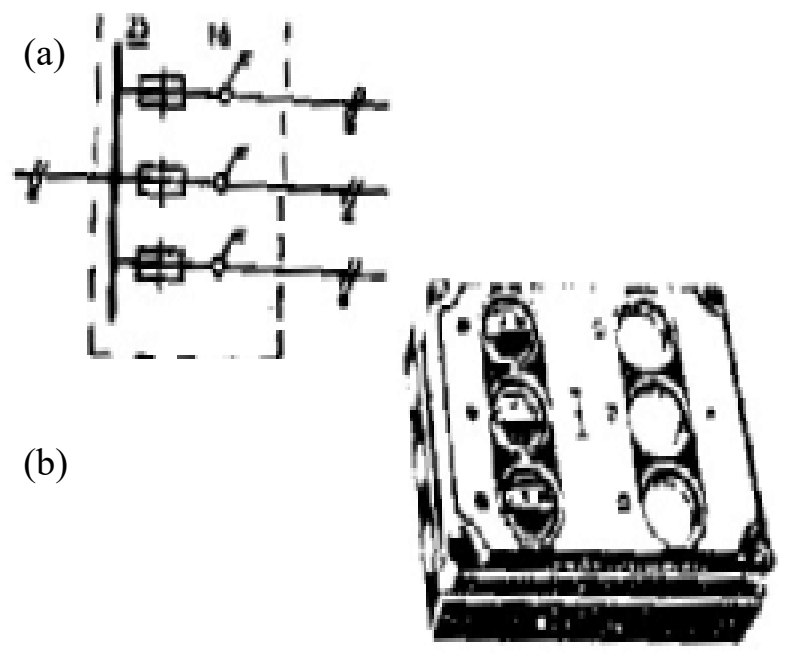

Gambar 5. Perlengkapan hubung bagi dan diagramnya 
Kontak hubung bagi juga harus memenuhi persyaratan antara lain :

1. Kontak hubung bagi harus kokoh, terbuat dari bahan yang tidak mudah terbakar dan tahan lembab

2. Pada kontak hubung bagi yang berdiri sendiri sekurang-kurangnya harus mempunyai satu saklar dengan kemampuan sakelar sekurangkurangnya sama dengan kemampuan arus nominal pengaman tetapi tidak kurang dari 10A.

3. Sakelar masuk boleh ditiadakan kalau kontak hubung bagi merupakan suplai dari hubung bagi lainnya

4. Setiap hantaran fasa keluar harus dipasang pengaman arus.

Komponen-komponen penting dari kontak hubung bagi adalah :

a. Kontak rel, (panel) berfungsi sebagai terminal untuk menyambungkan pada beberapa saluran ke beban.

b. Kotak pengaman

c. Kotak Sakelar yang merupakan satu kesatuan dari kontak hubung bagi.

\section{8. $\quad$ Fiting}

Fiting adalah tempat memasang bola lampu listrik, dan menurut penggunaannya dapat dibagi menjadi tiga jenis : fiting langit-langit, fiting gantung, dan fiting kedap air.

\section{a. Fiting Langit-Langit}

Pemasangan fiting langit-langit ditempelkan pada langit-langit (eternit) dan dilengkapi dengan roset. Roset diperlukan untuk meletakan/penyekerupan fiting supaya kokoh kedudukannya pada langit-langit.

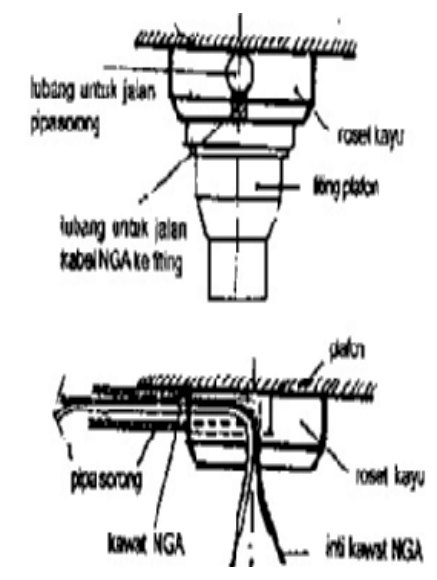

\section{B. Fiting Gantung}

Pada fiting gantung dilengkapi dengan tali snur yang berfungsi sebagai penahan beban bola lampu dan kap lampu, serta untuk menahan konduktor dari tarikan beban tersebut. Konstruksi dari fiting gantung dapat dilihat pada gambar 7 .

Gambar 7. Konstruksi fiting gantung

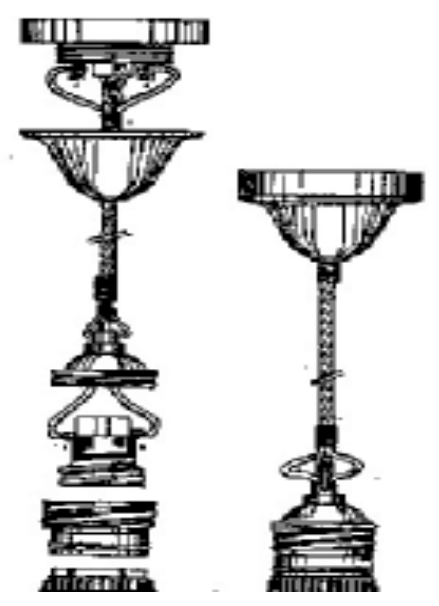

\section{Fiting Kedap Air}

Fiting kedap air merupakan fiting yang tahan terhadap resapan/rembesan air. Fiting jenis ini dipasang di tempat lembab atau tempat yang mungkin bisa terkena air misalnya fiting untuk di kamar mandi. Konstruksi fiting ini terbuat dari porselin, dimana bagian kontaknya terbuat dari logam kuningan atau tenbaga dan bagian ulirnya dilengkapi dengan karet yang berbentuk cincin sebagai penahan air. Konstruksi fiting kedap air dapat dilihat apada gambar 8 .

Gambar 8. Konstruksi fiting kedap air

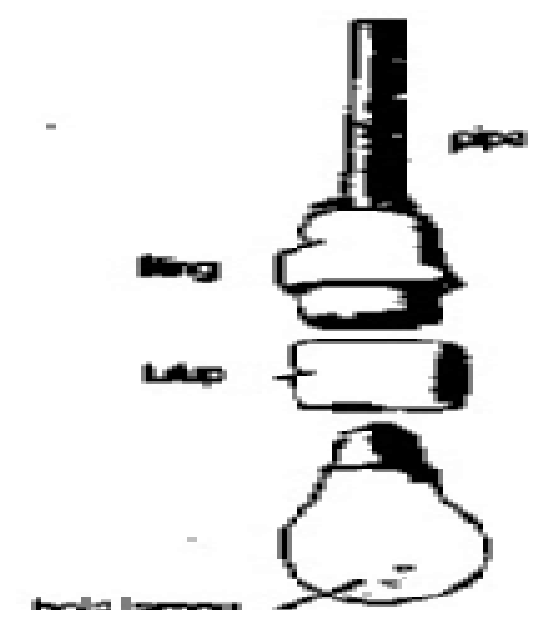




\section{Sakelar}

Sakelar berfungsi untuk memutuskan dan menghubungkan rangkaian listrik. Sakelar dan pemisah harus memenuhi beberapa persyaratan antara lain :

a. Dapat dilayani secara aman tanpa harus memerlukan alat bantu

b. Jumlahnya harus sesuai hingga semua pekerjaan pelayanan, pemeliharaan, dan perbaikan instalasi dapat dilakukan dengan aman.

c. Dalam keadaan terbuka, bagian sakelar atau pemisah bergerak harus tidak bertegangan (ayat $206 \mathrm{~B} 1$ ).

d. Harus tidak dapat terhubungkan sendiri karena pengaruh gaya berat (ayat $206 \mathrm{~B} 1$ ).

e. Kemampuan sakelar minimal sesuai dengan gaya daya alat yang dihubungkannya, tetapi tidak boleh kurang dari $5 \mathrm{~A}$ (ayat $840 \mathrm{C6}$ ).

Simbol atau lambang dari alat pemutus/penghubung ini dapat dilihat pada gambar 2.7. Dari gambar tersebut dapat dilihat konstruksi berbagai jenis sakelar, bentuk, serta cara penggambarannya.

Gambar 9. Simbol sakelar dan cara penggambarannya.

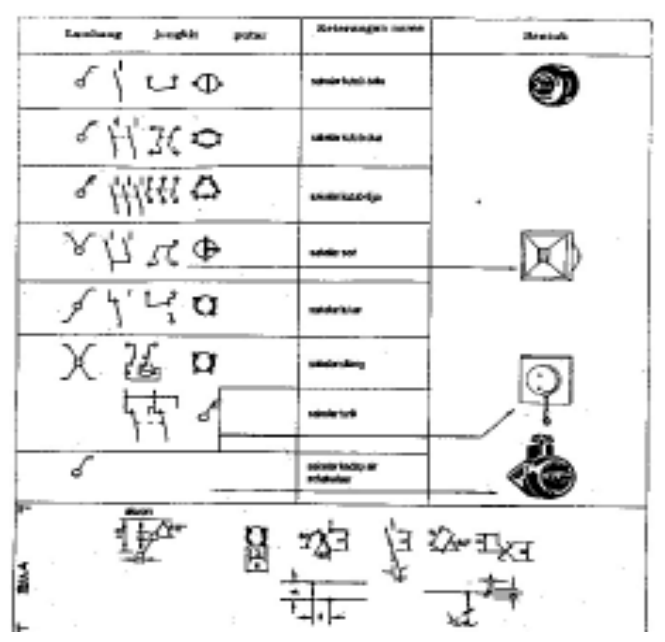

\section{BAHAN DAN METODE}

\section{A. KERANGKA PEMECAHAN MASALAH}

Teknik dalam aplikasi pemecahan masalah adalah memberikan suatu ilustrasi dan kejadian riil dalam kehidupan tentang hal kelistrikan di lingkungan sehari-hari, sehingga peserta dapat termotivasi untuk mengikuti kajian teori tentang teknik instalasi listrik 1 fase sesuai dngan PUIL tahun 2010.

Untuk itu diperlukan trik-trik agar peserta pelatihan mampu menerapkannya dalam kehidupan sehari-hari, dengan langkah-lagkah sebagai berikut:

1. Mengetahui kemampuan awal pada ranah kognitif dengan pre test tentang teknik instalasi listrik.

2. Memberikan penjelasan tentang kelistrikan 1 fase.

\section{B. REALISASI PEMECAHAN MASALAH}

Sebelum pelaksanaan Life Skill tentang Teknik Instalasi Listrik, maka terlebih dahulu diberikan Kajian teori pendukung dan teori Praktik agar peserta P2M benar benar memahami secara teoritis serta praktis, kemudian melakukan pembagian kelompok agar bias saling bekerja sama, kemudian memberikan Job sheet yang disesuaikan dengan alat serta bahan yang ada.

Adapun acara praktik selesai maka diadakan Tanya jawab serta evaluasi apa yang terjadi selama kegiatan berlangsung dan factor K3 yang harus diperhatikan.

\section{KHALAYAK SASARAN}

Adapun khalyak sasaran dipilih khusus masyarakat Eks TKI di Kabupaten Subang, yaitu para pria dan wanita sejumlah 13orang, dengan syarat pernah duduk di bangku SMP atau SMA/ SMK sehingga mudah menelaah dan merealisasikan materi yang ada di P2M berupa kajian teori dan job sheet.

\section{METODE YANG DIGUNAKAN}

Adapun metode yang dipergunakan dalam pelatihan ini, dipergunakan sebanyak 4 metode, yaitu:

1. Metode Ceramah

2. Metode Demontrasi/ peragaan

3. Metode Diskusi/tanya jawab

4. Metode ketrampilan praktik/Psikomotorik

\section{PEMBAHASAN DAN HASIL}

\section{A. PEMBAHASAN}

Pelaksanaan kegiatan pengabdian kepada masyarakat Eks TKI di Kabupaten Subang ini dapat berjalan sesuai dengan rencana program yang telah ditentukan baik dari segi waktu, 
tempat pelaksanaan, narasumber, pimpinan LPM beserta Staffnya dan peserta pelatihan semua memberikan konstribusi yang baik kelancaran kegiatan P2M ini. Pelaksanaan Pelatihan P2M tentang Pengetahuan dan Ketrampilan Teknik Instalasi listrik AC 1 Fase bagi eks TKI di Kecamatan Pegaden, Kabupaten subang, Provinsi Jawa Barat diberikan teori dan praktik yang dilaksanakan pada hari sabtu, 04 Juni 2016 di Ruang aula Desa Kamarung, Kecamatan Pagaden, Kabupaten Subang, Provinsi Jawa Barat. Selama kegiatan pelatihan para peserta Eks TKI pria dan wanita sebanyak 13 orang se Kecamatan Pagaden sangat serius dan antusias sekali mengikutinya mulai dari awal sampai akhir kegiatan ini, baik pengetahuan teori dan ketrampilan praktik teknik instalasi listrik.

\section{B. HASIL KEGIATAN P2M}

Suatu kegiatan dapat tercapai apabila target yang diharapkan sesuai dengan program yang telah ditentukan dan disepakati, yaitu adanya beberapa syarat peserta didik yang terpenuhi, perizinan yang dilakukan serta persiapan ke lokasi sasaran, mengingat kegiatan di masyarakat Eks TKI di Kabupaten Subang, maka diperlukan persiapan persiapan yang lengkap dan memadai, agar benar benar pelaksanaan dapat berjalan lancar, aman dan terukur.

Ada beberapa hal hasil yang tercapai saat pelaksanaan P2M, yang antara lain:

1. Kepedulian masyarakat Eks TKI pria dan wanita terhadap kelistrikan sangatlah antusias.

2. Peserta pelatihan Eks TKI di Kabupaten Subang sangat berperan aktif, karena ketrampilan instalasi listrik sangat bermanfaat buat di rumah sendiri dan masyarakat.

3. Kemampuan praktik para Eks TKI pria dan wanita di Kabupaten Subang memperoleh hasil yang memuaskan karena peserta sebelum sudah diberikan pengetahuan praktis tentang kelistrikan dan bahaya2nya. Serta solusi dalam menanggulanginya.

4. Kegiatan pengabdian pada masyarakat bagi warga Eks TKI pria dan wanita sebanyak 13 orang, sangatlah membantu pencerahan tentang masalah kelistrikan, baik teknik instalasi listrik penerangan atau cahaya dan tenaga atau gerak.

\section{KESIMPULAN DAN SARAN}

A. KESIMPULAN

Pengabdian pada masyarakat / warga Eks TKI di Kecamatan Pagaden, Kabupaten Subang, Jawa Barat tetang pengetahuan dan ketrampilan teknik Instalasi listrik AC 1 fase untuk rumah tinggal, maka dapat diperoleh kesimpulannya sebagai berikut:

1. Sangat kuat dan motivasi yang tinggi dari para peserta pengabdian pada masyarakat terutama kalangan Eks TKI pria dan wanita dalam mengikuti kegiatan P2M ini.

2. Salah satu tri Darma Perguruan Tinggi adalah Pengabdian pada masyarakat sangatlah positif untuk mengaplikasikan pengetahuan praktis kepada masyarakat di luar kampus.

3. Perhatiannya Kepala Desa kamarung, kecamatan Pegaden, Kabupaten Subang, Jawa Barat dan staffnya untuk mensosialisasikan adanya kegiatan P2M dari LPM UNJ sangatlah tinggi.

\section{B. SARAN - SARAN}

Mengingat salah satu Tri darma Perguruan Tinggi, maka :

1. Sudah sepatutnya Universitas negeri Jakarta bekerja sama dengan Pemerintah Daerah Kabupaten Subang, Jawa Barat untuk kegiatankegiatan Pengabdian Pada Masyarakat yang tepat guna dan tepat sasaran, khususnya dan pada umumnya Pemerintah Provinsi Jawa Barat. Sehingga manfaat pengabdian masyarakat benar-benar turun ke bawah atau kelapangan.

2. P2M merupakan wujud nyata kepedulian masyarakat kampus terhadap lingkungannya, maka perlu dibina dan adanya maping.

\section{DAFTAR PUSTAKA}

Dikmenjur, Ketrampilan Teknik Instalasi Listrik, Jakarta, tahun 2000.

Dikmenjur, Petunjuk Praktik Teknik Instalasi Listrik, Jakarta, tahun 2002.

Dikmenjur, Perencanaan Instalasi Listrik, Jakarta, Tahun 1995.

E. Setiawan \& Van Harten, Instalasi Listrik Arus Kuat 1,2, BinaCipta, Jakarta, 2003.

LIPI, Persyaratan Umum Instalasi Listrik (PUIL), Jakarta, tahun 2010.

Zan, Scbotsman, Instalasi edisi kelima, Erlangga, Jakarta, tahun 2001. 